DOI: https://doi.org/10.15407/techned2019.05.043

\title{
DETERMINATION OF THE COEFFICIENT OF THE TRANSFORMATION OF A CURRENT PARAMETER BRIDGE OF A SINGLE-PHASE RECTIFIER WITH PARALLEL ACTIVE-CAPACITIVE LOAD
}

Journal
Publisher
ISSN
Issue
Pages

\author{
Tekhnichna elektrodynamika \\ Institute of Electrodynamics National Academy of Science of Ukraine \\ 1607-7970 (print), 2218-1903 (online) \\ No 5, 2019 (September/Oktober) \\ $43-48$
}

\author{
Authors \\ V.M. Spirin ${ }^{\star}$, V.M. Hubarevich ${ }^{\star *}$, Yu.V. Marunya ${ }^{\star \star \star}$, S.V. Salko, V.G. Grebenyuk \\ Institute of Electrodynamics National Academy of Sciences of Ukraine, \\ pr. Peremohy, 56, Kyiv, 03057, Ukraine, \\ e-mail: sspirin@ied.org.ua \\ * ORCID ID : http://orcid.org/0000-0002-8065-1051 \\ ** ORCID ID : http://orcid.org/0000-0003-2416-9858 \\ *** ORCID ID : http://orcid.org/0000-0003-0071-1702
}

\section{Abstract}

In this work the experiments were carried out in accordance with the theory of planning according to the second order orthogonal plan for the electrical system: inductive-capacitive converter (ICC) of the voltage source in the current source - single-phase bridge rectifier parallel active-capacitive load. As factors, the following relative indicators are selected: for the first factor, this capacitance of the output filter condenser is assigned to the capacitance value of the capacitor of the ICC, for the second factor of the load resistance relation to the ICC input impedance. The objective functions in the implemented plan were: the coefficient of transformation of the rectifier by current and the conversion factor of the rectifier by voltage, current pulsation coefficient $\left(k_{n}\right)$, current harmonic coefficient (THDi ). For these functions, the goals are obtained by polynomials of the second order, having a convergence with the values obtained experimentally, less than 3\%, and confirm the correctness of the chosen plan of experiments. For the transform coefficient of the rectifier by voltage, an analytical formula is obtained for its calculation, which gives convergence with experimental values less than $10 \%$. The considered electrical system of the source of the stabilized current has good 
electromagnetic compatibility with the power supply network, which is confirmed by another function of purpose (THDi), which was implemented according to an orthogonal plan of the second order and whose value in the two-factor space does not exceed 5,5\%. The analytical and experimental values of the transformation coefficients of the current-parameter single-phase bridge rectifier obtained by current and voltage allow to calculate and determine the output characteristics of the ICC.

References 6, figures 5, table 1.

Key words: rectifier, inductive-capacitive converter, conversion factor, active capacitive load

Received: 13.03 .2019

Accepted: 02.05.2019

Published: 01.08.2019

\section{References}

1. Spirin V.M., Gubarevich V.M., Salko S.V., Maruna Yu.V. Improvement of electromagnetic compatibility of single-phase bridge rectifier with parallel active-capacitive loading. Pratsi Instytutu Elektrodynamiky NAN Ukrainy

. 2018. Vol. 50. Pp. 83-87. (Ukr)

DOI:

https://doi.org/10.15407/publishing2018.50.083

2. Bideev G.A., Mendybayev S.A., Obukhov SG, Pavlov F.V., Ukharsky M.V. Control system for regulated reversing current-voltage valve transducer. Scientific and technical conf. Problems of the transformational technique , Kiev,

Ukraine, 1979. Pp. 190-193. (Rus)

3. Pinchuk S.I. Organization of the experiment in modeling and optimization of technical systems. Dnepropetrovsk: Diva, 2008. 248 p. (Rus)

4. Korn G., Korn T. The reference book on mathematics. Moskva: Nauka, 1968. 720 p. (Rus)

5. Yudin Yu.V., Maysuradze M.V., Vodolazsky F.V. Organization and mathematical planning of the experiment. Ekaterinburg: Publishing House Ural. University, 2018. 124 p. (Rus)

6. Spirin V.M. Power supply system for electric arc devices with a negative differential resistance: author's abstract of Dr. tech. sci. diss.: 05.09.03. Institute of Electrodynamics of NAS of Ukraine. Kyiv. 2013. 35 p. (Ukr) 


\section{PDF}

